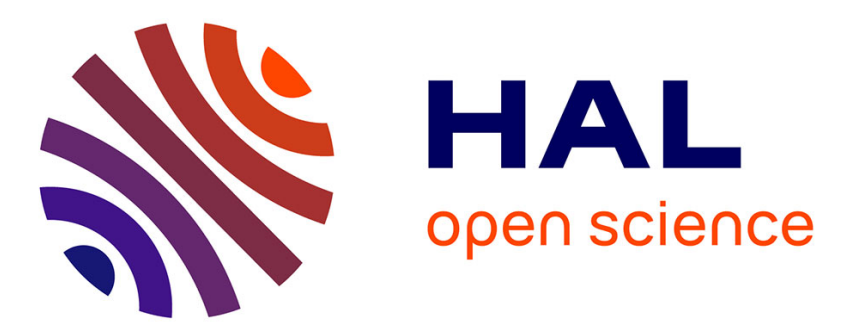

\title{
Mathematical relation of steel thickness loss with time related to reinforced concrete contaminated by chlorides
}

Véronique Bouteiller, Elisabeth Marie Victoire, Christian Cremona

\section{To cite this version:}

Véronique Bouteiller, Elisabeth Marie Victoire, Christian Cremona. Mathematical relation of steel thickness loss with time related to reinforced concrete contaminated by chlorides. Construction and Building Materials, 2016, 124, pp 764-775. 10.1016/j.conbuildmat.2016.07.078 . hal-01361186v2

\section{HAL Id: hal-01361186 \\ https://hal.science/hal-01361186v2}

Submitted on 20 Oct 2017

HAL is a multi-disciplinary open access archive for the deposit and dissemination of scientific research documents, whether they are published or not. The documents may come from teaching and research institutions in France or abroad, or from public or private research centers.
L'archive ouverte pluridisciplinaire HAL, est destinée au dépôt et à la diffusion de documents scientifiques de niveau recherche, publiés ou non, émanant des établissements d'enseignement et de recherche français ou étrangers, des laboratoires publics ou privés. 
Mathematical relation of steel thickness loss with time related to reinforced concrete contaminated by chlorides.

Véronique Bouteiller $^{\left.a,{ }^{*}\right)}$, Elisabeth Marie-Victoire ${ }^{b)}$ and Christian Cremona ${ }^{a, c)}$

a) Université Paris-Est, IFSTTAR, MAST, SDOA, F-77447 Marne-la-Vallée, France

b) LRMH, CNRS-USR 3224, Laboratoire de Recherche des Monuments Historiques, Champs sur Marne, France, elisabeth.marie-victoire@culture.gouv.fr

c) from a), Present address: Bouygues, France, c.cremona@bouygues-construction.com

\title{
* Corresponding author
}

E-mail address: veronique.bouteiller@ifsttar.fr

Postal address: IFSTTAR, MAST / SDOA, Cité Descartes, 14-20 Boulevard Newton, 77447 ChampsSur-Marne, Marne La Vallée, Cedex 2, France

Tel: +33181668113;

\begin{abstract}
Corrosion of chloride contaminated reinforced concretes exposed to outdoor conditions and to six controlled environmental conditions was followed within a five year study. Corrosion was evaluated four times a year performing visual observations (rust, cracks, delamination) and electrochemical measurements from which corrosion rates were calculated. These latter values were converted in cumulative steel thickness loss versus cumulative time in order to propose a mathematical relation for simulating corrosion in the propagation phase. It was found that a mathematical power relation fitted the experimental data better than a linear relation.
\end{abstract}

\section{Keywords}

Reinforced concrete; Chlorides; Corrosion, Electrochemical characterizations; Mathematical relation; Durability; Prediction.

\section{Highlights}

- Intensive and long term experimental program on corrosion of reinforced concrete in its propagation phase 
- Controlled and outdoor environmental conditions

- Database for further numerical studies

- Mathematical relation of cumulative steel thickness loss with time

- Reliability in simulating / predicting the corrosion of reinforced concrete and its durability

\section{Introduction}

Reinforced concrete is a composite engineering material widely used in the construction industry (buildings, bridges, tunnels, nuclear plants, historical monuments, etc.). One of the major factors responsible for the deterioration of these structures is the corrosion of the reinforcement [1-6] which may result in damages in the form of rust spots, cracking and even delamination of the concrete cover (risk for end-users). In addition, the structural damage may consist in loss of a reinforcement crosssectional area and loss of bond between reinforcement and concrete, resulting in loss of serviceability and structure safety.

Experimental study of the rebar's corrosion in concrete is a difficult task because of the high number of parameters that are involved [7]. They can be gathered in three interactive groups: (i) concrete states, (ii) environmental conditions and (iii) corrosion tests. Concerning the concrete states, the presence of chloride ions has been extensively studied [8-10] for the determination of the chloride level threshold that initiates corrosion and this is still in discussion today. The concrete formulation also interacts with the corrosion process: Bouteiller have studied the corrosion initiation due to chloride ions on pre-cast components made with either ordinary Portland cement or Portland cement with $70 \%$ blast furnace slag [11]. Reinforced concrete specimen size is another relevant parameter [12]. The influence of the environmental conditions (controlled temperature and relative humidity or natural weathering) has been studied [13-19]. Moreover, under laboratory control, different authors have studied the corrosion process related to the oxygen content [20-22]. At last, depending on the investigation method, the testing device, the experimental condition (laboratory or in situ), corrosion results can also be difficult to compare [23-29].

Studying the corrosion of rebar in concrete requires electrochemical characterizations that rely upon half-cell potential, resistance or resistivity and linear polarisation resistance. For several decades, the civil engineering diagnosis has relied upon half-cell potential mapping [30]. With some care this technique can be used quite successfully to identify areas of the structure which may be suffering from 
corrosion attack. However it gives no information about the rate at which corrosion may be occurring. The measurement of concrete resistivity is also a qualitative technique [31]. It has been suggested that the presence of a low concrete resistivity in the regions indicated as being actively corroding by half-cell potential mapping can be used as an indicator that the rate of corrosion in probably quite high. The linear polarization resistance (LPR) technique can provide quantitative information on the corrosion rate of reinforcing steel [27]. This technique has seen a growth in popularity in recent years and is beginning to see more widespread use as an effective non-destructive test for the evaluation of reinforced concrete structures at risk for corrosion attack [18, 23, 25-28, 32-38]. When the technique is to be used in situ, there is concern about the variability of measurements and the influence of fluctuations due to environmental conditions.

As reported in the literature $[39,40]$, modelling and/or predicting the durability of reinforced structures highlight the lack of experimental studies dealing with the corrosion in its propagation phase.

The aim of this paper is to propose a mathematical relationship between cumulative steel thickness loss and time, in the propagation phase of the corrosion. Therefore reinforced concretes contaminated by chloride ions (in the mix or by wetting/drying cycles) were exposed to different environmental conditions (controlled and outdoor) and their corrosion was studied during a five year period.

\section{Materials and methods}

\subsection{Concrete states}

Reinforced concrete slabs $(300 \times 300 \times 50 \mathrm{~mm}$ with 5 parallel rebars) which concrete composition is given in Table 1 had a $30 \mathrm{MPa}$ compressive strength. Water to cement ratio was chosen equal to 0.7 which is of course very high for new constructions but that was usually used decades ago in structures from historical monuments or civil engineering. These ancient structures are the ones that are corroding today. Slabs were casted and/or aged to study three different states. Slabs "T" were sound reinforced concrete (used as reference). Slabs "G" were contaminated with $5 \%$ of $\mathrm{NaCl}$ by weight of cement added in the mix. Slabs "I" contained chlorides that have penetrated by wetting and drying cycles (salted pond $\mathrm{NaCl} 35 \mathrm{~g} / \mathrm{L}$, during 12 months). 
Table 1: Concrete composition $\left(\mathrm{kg} / \mathrm{m}^{3}\right)$.

\begin{tabular}{lllllllll}
\hline \multicolumn{1}{l}{ Cement (CEM I 52.5 N CE CP2 NF) } \\
\hline \multicolumn{1}{l}{ Water } & & & & & & & 275 \\
\hline Palvadeau aggregates & 149 & 277 & 180 & 170 & 57 & 324 & 265 & 473 \\
(size mm) & $0 / 0.315$ & $0.315 / 1$ & $0.5 / 1$ & $1 / 4$ & $2 / 4$ & $4 / 8$ & $8 / 12$ & $12.5 / 16$ \\
\hline
\end{tabular}

\subsection{Reinforced concrete prisms}

Specimens of the study were reinforced concrete prisms that were sawed from the slabs described previously (10 prisms per slab). The prisms T, G and I (which dimensions were 150x50x50 mm) contained a central rebar with an uninsulated steel surface area equal to $18.85 \mathrm{~cm}^{2}$ (length $100 \mathrm{~mm}$ and diameter $6 \mathrm{~mm}$ ). More details for describing the specimens can be found in [17]. Total [41] and free [42] chloride contents (in $\mathrm{g} \%$ by weight of cement) were respectively equal to 2.7 and 1.4 for prism $n^{\circ} 639-\mathrm{G}$ and to 4.8 and 3.1 for prism $n^{\circ} 664-$ I. For both chloride contaminations, the chloride content was higher than $0.4 \%$ by weight of cement (this ratio usually refers to a condition for which corrosion is likely to occur [43]) and therefore rebar's corrosion was considered to be in the propagation phase. Five reinforced concrete prisms per state were exposed to seven environmental conditions meaning a total of 105 studied specimens.

\subsection{Environmental conditions}

Six controlled environmental conditions were considered based on two temperatures $\left(20^{\circ} \mathrm{C}\right.$ and $\left.45^{\circ} \mathrm{C}\right)$ and three relative humidities $(60 \%, 80 \%$ and $92 \%)$. The outdoor condition consisted in the suburb of Paris where temperature and relative humidity recorded from September 2008 to January 2014 respectively varied within a range of -10 to $+30^{\circ} \mathrm{C}$ and of 29 to $91 \% \mathrm{RH}$ (Figure 1). Precipitations varied from 0 to $4 \mathrm{~cm} /$ day except for $20^{\text {th }}$ December $2009(12 \mathrm{~cm})$. These ranges were coherent with the French climate (except for the high precipitations in December 2009).

\subsection{Measurement termed points}

The following of the corrosion of the reinforced concrete prisms (visual observations and electrochemical characterizations) was carried out 4 times a year from 2008 to 2014 (except for $45^{\circ} \mathrm{C}$ and $80 \% \mathrm{RH}$ because the chloride contaminated prisms were delaminated after 12 to 18 months). 

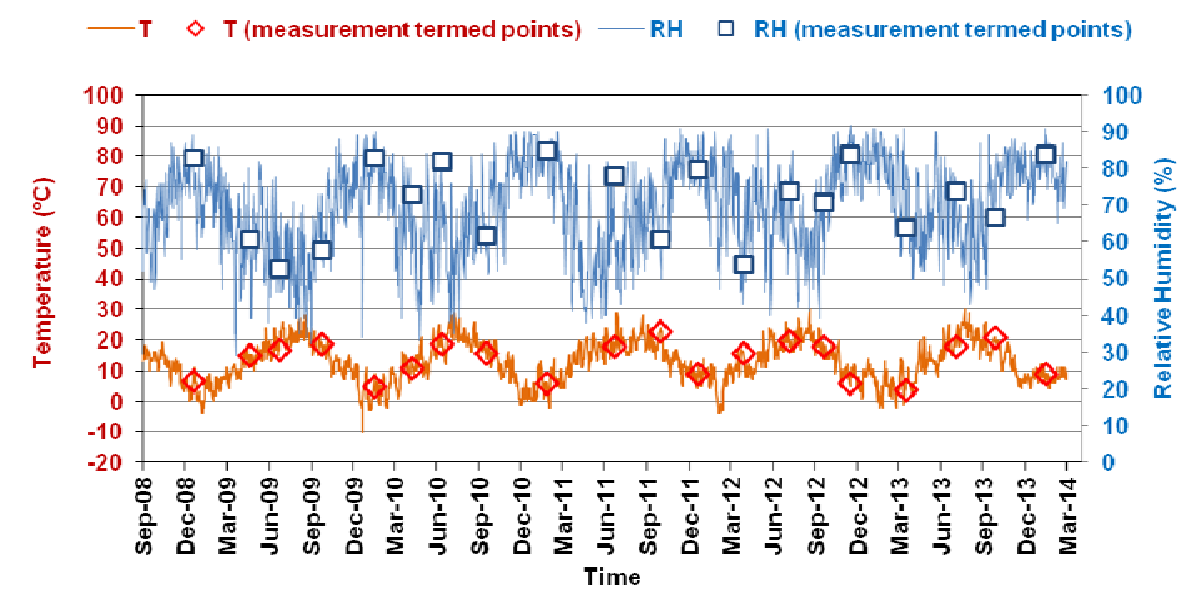

Figure 1: Temperature and relative humidity values from September 2008 to January 2014 in the suburb of Paris. Temperature and relative humidity at the measurement termed points are also indicated.

\subsection{Visual inspections of prisms}

A visual inspection of each prism was carried out with time to ascertain corrosion signs such as rust spots, rust leaching, cracks or delaminations. More than 3000 pictures were taken and comments were added to the database.

\subsection{Electrochemical tests}

In order to calculate the corrosion rate of the prism's rebar, three non-destructive techniques were used: half cell potential (HCP) monitoring, electrochemical impedance spectroscopy (EIS) and linear polarization resistance (LPR). Twenty four hours before measurements, the prisms were taken out of their environmental conditions and were placed in the laboratory conditions $\left(20^{\circ} \mathrm{C}\right.$ and $\left.60 \% \mathrm{RH}\right)$. Then, all the measurements were performed the same day. The electrochemical system was composed of three electrodes: the working electrode was the steel rebar, the reference electrode was a $\mathrm{KCl}$ (potassium chloride) saturated calomel electrode (SCE, $\mathrm{E}(\mathrm{NHE})=242 \mathrm{mV}$ ) and the counter electrode was a titanium/platinum-based grid. The electrical contact was provided by a wetted (tap water) sponge. The measurements were conducted using a multichannel Bio-Logic potentiostat (VMP2Z model) and the EC-Lab 10.12 software. For the sound concrete prisms $\mathrm{T}$ a low current capability was used because the current values were in the nanoAmpere range.

The Ecorr value ( $\mathrm{mV}, \mathrm{SCE}$ ), was determined as the HCP measurement after a 10 min period which was long enough to obtain a stabilized signal. EIS measurements were performed using a $10 \mathrm{mV}$ amplitude sine wave signal in the frequency range between $100 \mathrm{kHz}$ and $100 \mu \mathrm{Hz}$ with five points per 
decade and the Re value (Ohm) was determined at high frequency. For LPR measurements, a potential variation ( $\pm 10 \mathrm{mV}$ around the half-cell potential Ecorr using a sweep rate of $2.5 \mathrm{mV} / \mathrm{min}$ ) was imposed and the current was recorded. The slope of the curve which is equal to (1/Re+Rp) was determined from the values obtained between 0 and $+10 \mathrm{mV}$ around Ecorr. The polarization resistance of the steel rebar, Rp (Ohm), was then calculated knowing the Re value (previously determined by EIS). Finally, corrosion current density $\mathrm{i}_{\text {corr }}\left(\mu \mathrm{A} / \mathrm{cm}^{2}\right)$ also named corrosion rate was calculated from the Stern and Geary equation [44]: $\mathrm{i}_{\text {corr }}=\mathrm{B} / \mathrm{Rp} . \mathrm{S}$ where $\mathrm{B}$ is a constant (considered as $26 \mathrm{mV}$ [32], Rp the polarization resistance (ohm) taking into account the ohmic drop and S the steel surface area of the rebar $\left(18.85 \mathrm{~cm}^{2}\right.$ in this study)). For each concrete state $(T, G$ and I) corrosion rate was calculated as the average of the five prisms per environmental conditions (or less if autopsy or delaminated prisms) and analysed considering the four levels of corrosion suggested by the RILEM [27]: negligible $\left(\mathrm{i}_{\text {corr }}<0.1 \mu \mathrm{A} / \mathrm{cm}^{2}\right)$, low $\left(0.1-0.5 \mu \mathrm{A} / \mathrm{cm}^{2}\right)$, moderate $\left(0.5-1 \mu \mathrm{A} / \mathrm{cm}^{2}\right)$ and high $\left(\mathrm{i}_{\text {corr }}>1\right.$ $\left.\mu \mathrm{A} / \mathrm{cm}^{2}\right)$. Performing electrochemical measurements became impossible when the cracks became too important or when the prism was delaminated.

\subsection{Calculations of cumulative steel thickness loss versus cumulative time}

The values of $\mathrm{i}_{\text {corr }}$ were calculated four times per year. Then the mass loss and the steel thickness loss (which is more useful than corrosion rates for civil engineers) were calculated using the following equations:

$$
\text { Mass loss (Faraday's law): } \quad m=\frac{M}{F z} i t \quad \text { (ing) }
$$

Where $M=$ atomic weight of iron $(55.8 \mathrm{~g} / \mathrm{mol}), F=$ Faraday's constant $\left(96500 \mathrm{C} \cdot \mathrm{mol}^{-1}\right), z=$ ionic charge of metal $\left(\mathrm{z}=2 ; \mathrm{Fe} \rightarrow \mathrm{Fe}^{2+}+2 \mathrm{e}^{-}\right), i=$ current $(\mathrm{A})$ calculated as the average of $\mathrm{i}_{\text {corr }}$ in between two measurement termed points and $t=$ duration (s) in between two measurement termed points.

$$
\text { Steel thickness loss: } \quad \text { stl }=R-r
$$

where $\mathrm{R}$ and $\mathrm{r}$ are respectively the initial radius of the rebar and the radius at time $\mathrm{t}$

$$
\begin{gathered}
\text { Mass loss (geometry) } \quad m=\pi . L . \rho\left(R^{2}-r^{2}\right)=\pi \cdot L \cdot \rho .2 . R . s t l=S . \rho . s t l \\
==>\text { Steel thickness loss : } \quad \text { stl }=\frac{10000 m}{\rho S}(\text { in } \mu \mathrm{m})
\end{gathered}
$$

Where $\rho=$ density of metal $\left(7.874 \mathrm{~g} / \mathrm{cm}^{3}\right.$ for steel $)$ and $S=$ surface of steel area $\left(18.85 \mathrm{~cm}^{2}\right)$.

Finally the cumulative steel thickness loss $(\mu \mathrm{m})$ was plotted versus the cumulative time (days). 


\section{Results}

\subsection{Visual inspections}

Sound reinforced concrete prisms $(\mathrm{T})$ showed no sign of corrosion during the five year study. For the chloride contaminated prisms, time for the appearance of first visual corrosion signs (rust, cracks, delamination) and prisms state after 60 month are gathered in Table 2 depending on the environment conditions. The evolution of visual corrosion signs for $\mathrm{G}$ prisms (at 15, 24, 45 and 60 months) is illustrated in Figure 2. Although the five prisms exposed to one environment were all similar (same ageing), visual signs of corrosion did not appear after the same duration: for example, at $20^{\circ} \mathrm{C}$ and $80 \% \mathrm{RH}$ only one out of five $\mathrm{G}$ prisms showed small cracks after 45 months, then $2 / 5$ after 54 months and at 60 months two prisms showed no sign of corrosion, 1 prism showed rust and 2 prisms showed small cracks (Figure 2). At $20^{\circ} \mathrm{C}$, signs of corrosion for $\mathrm{G}$ prisms appeared later on compared to I prisms (Table 2) and this could be explained by the higher chloride content in I prisms (§ 2.2). However, this trend was not confirmed for $45^{\circ} \mathrm{C}$. Higher temperature and/or higher relative humidity lead to a higher degradation. The most detrimental environmental conditions were $45^{\circ} \mathrm{C}$ and $80 \% \mathrm{RH}$, and $45^{\circ} \mathrm{C}$ and $92 \% \mathrm{HR}$. In this latter condition, all the $\mathrm{G}$ prisms were delaminated after 12 months (33 months for I prisms). For prisms exposed to outdoor conditions (Table 2 and Figure 2), small cracks were noticed after 24 months on one out of five G prisms and after 18 months on one out of five I prisms. After 60 months, for $\mathrm{G}$ prisms, two prisms showed small cracks and two prisms showed cracks. For I prisms, one prism showed no sign of corrosion and three others showed small cracks.

Table 2: First visual sign of corrosion (time in months for the appearance, number of impacted prisms and description of corrosion) and situation after 60 months (or less if mentioned).

\begin{tabular}{lllll}
\hline & & \multicolumn{1}{c}{ I } & G \\
\hline $\begin{array}{l}\text { Environmental } \\
\text { condition }\end{array}$ & $\begin{array}{l}\text { First corrosion } \\
\text { sign }\end{array}$ & $\begin{array}{l}\text { After 60 months } \\
\text { (x prisms out of } 5)\end{array}$ & $\begin{array}{l}\text { First corrosion } \\
\text { sign }\end{array}$ & $\begin{array}{l}\text { After 60 months } \\
\text { (x prisms out of } 5)\end{array}$ \\
\hline $20^{\circ} \mathrm{C}, 60 \% \mathrm{RH}$ & $45 ; 1 / 5 ;(\mathrm{sc})$ & $2(\mathrm{sc})$ & - & $5(\mathrm{n})$ \\
$20^{\circ} \mathrm{C}, 80 \% \mathrm{RH}$ & $15 ; 1 / 5 ;(\mathrm{sc})$ & $1(\mathrm{n}) ; 3(\mathrm{r}+\mathrm{sc}) ; 1(\mathrm{sc})$ & $45 ; 1 / 5 ;(\mathrm{sc})$ & $2(\mathrm{n}) ; 1(\mathrm{r}) ; 2(\mathrm{sc})$ \\
$20^{\circ} \mathrm{C}, 92 \% \mathrm{RH}$ & $54 ; 1 / 5 ;(\mathrm{rl})$ & $2(\mathrm{a}) ; 2(\mathrm{n}) ; 1(\mathrm{r}+\mathrm{sc})$ & $57 ; 1 / 5,(\mathrm{sc})$ & $2(\mathrm{a}) ; 1(\mathrm{n}) ; 2(\mathrm{sc})$ \\
\hline $45^{\circ} \mathrm{C}, 60 \% \mathrm{RH}$ & $15 ; 1 / 5 ;(\mathrm{sc})$ & 57 months: $5(\mathrm{~d})$ & $45 ; 1 / 5,(\mathrm{sc})$ & $1(\mathrm{n}) ; 3(\mathrm{c}) ; 1(\mathrm{~d})$ \\
$45^{\circ} \mathrm{C}, 80 \% \mathrm{RH}$ & $15 ; 1 / 5 ;(\mathrm{sc})$ & 18 months: $5(\mathrm{~d})$ & $6 ; 1 / 5 ;(\mathrm{c})$ & 12 months: $5(\mathrm{~d})$ \\
$45^{\circ} \mathrm{C}, 92 \% \mathrm{RH}$ & $15 ; 1 / 5 ;(\mathrm{r})$ & 33 months: $2(\mathrm{a}) ; 3(\mathrm{~d})$ & $6 ; 1 / 5 ;(\mathrm{c})$ & 12 months: $1(\mathrm{a}) ; 4(\mathrm{~d})$ \\
\hline Outdoor & $18 ; 1 / 5 ;(\mathrm{sc})$ & $1(\mathrm{a}) ; 1(\mathrm{n}) ; 3(\mathrm{sc})$ & $24 ; 1 / 5 ;(\mathrm{sc})$ & $1(\mathrm{a}) ; 2(\mathrm{sc}) ; 2(\mathrm{c})$ \\
\hline
\end{tabular}

n: no corrosion sign; r:rust; rl: rust leaching; sc: small crack; c: crack; a:autopsy; ' as illustrated in Figure 2. 


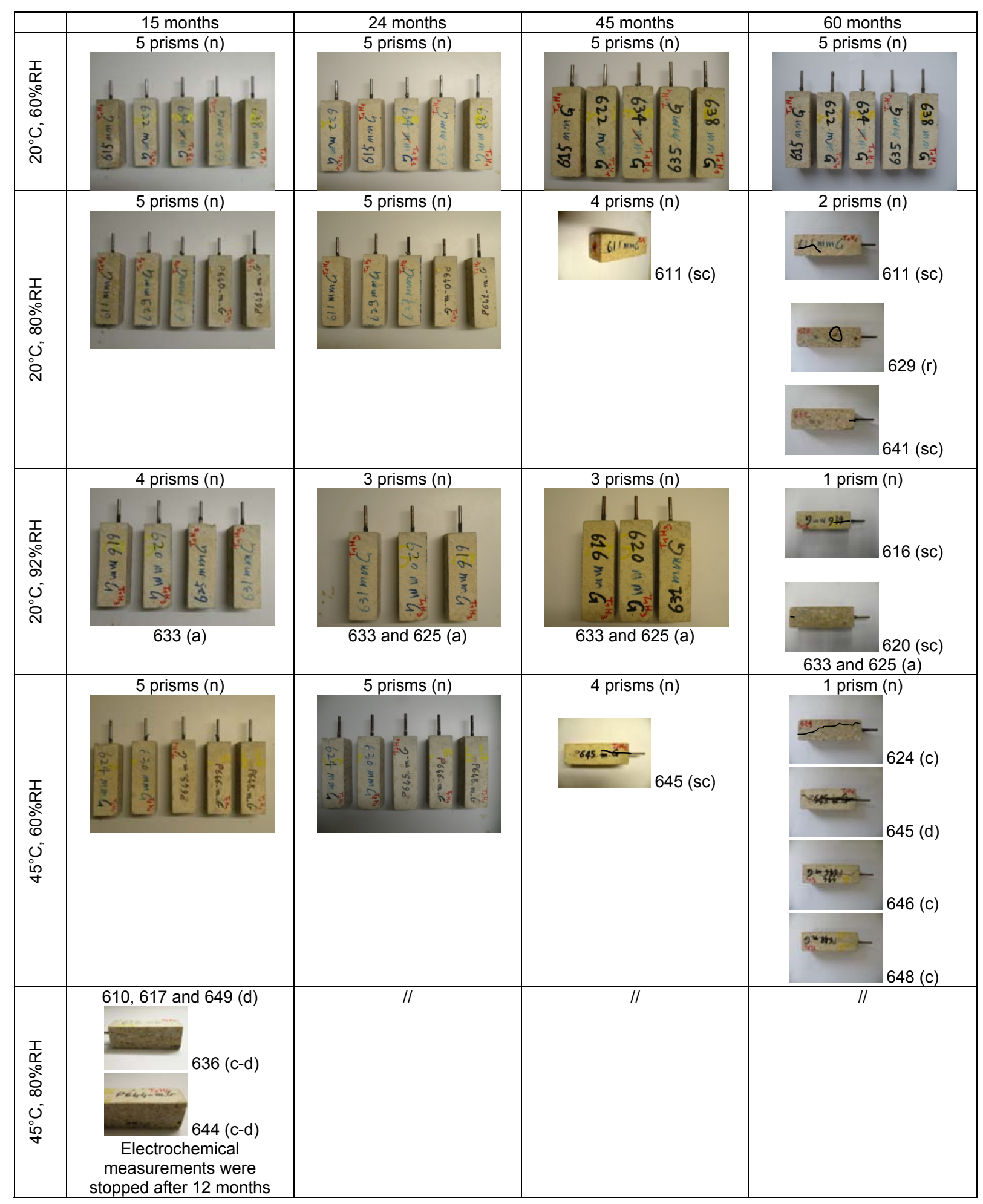




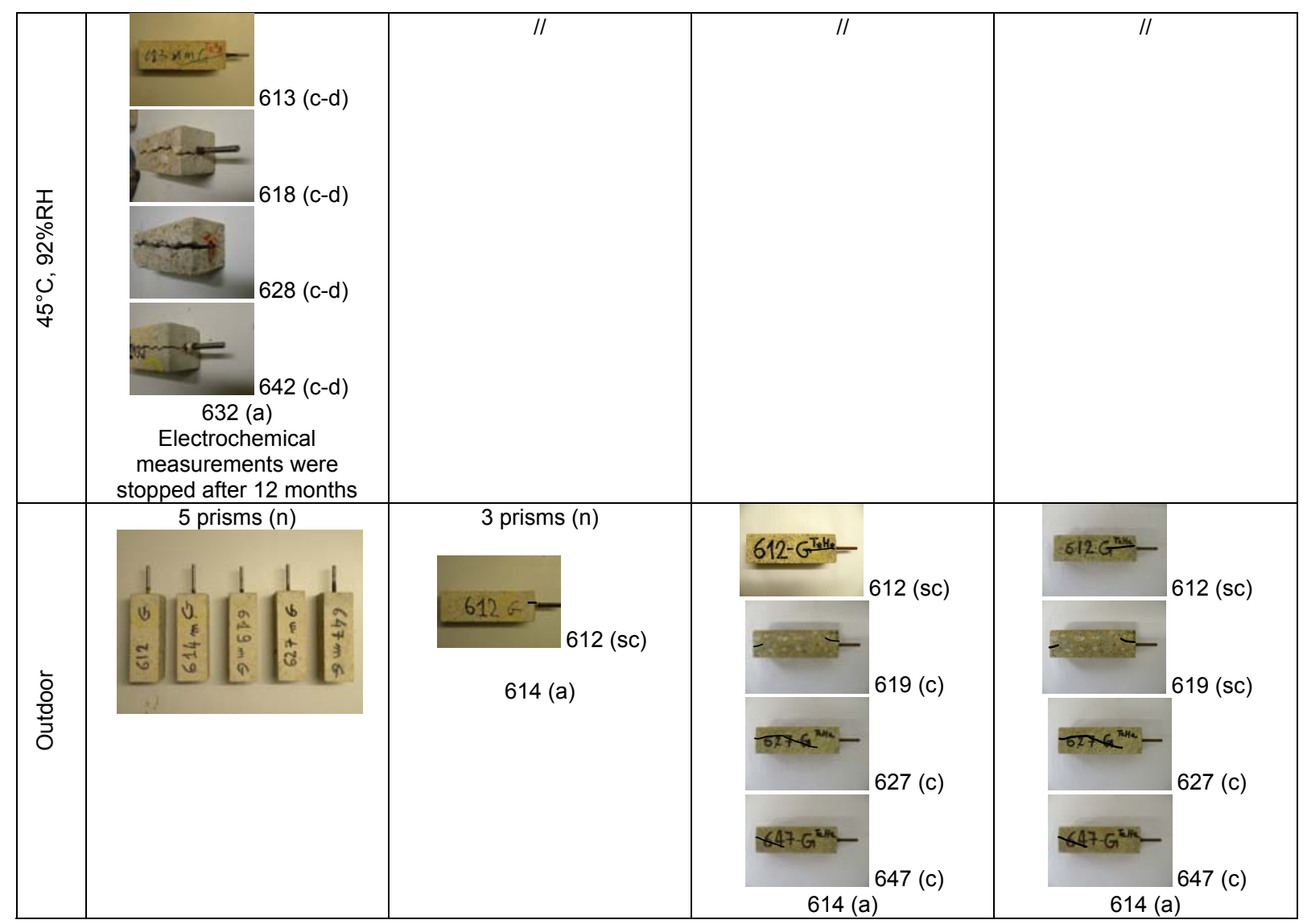

Figure 2: Evolution of visual corrosion signs for $G$ prisms depending on environmental conditions ( $n$ : no corrosion sign; $r$ : rust; sc: small crack; c: crack; d: delaminated; a: autopsy)

\subsection{Database}

A database (with more than 3000 values) gathered the whole measured and calculated electrochemical characterizations together with the comments from visual inspections. Table 3 is an extract of the database which presents the information for prism 612-G exposed to outdoor conditions. 
Table 3: Extract of the database (prism 612-G exposed to outdoor conditions).

\begin{tabular}{cccccccc}
$\begin{array}{c}\text { Termed } \\
\text { points } \\
\text { (months) }\end{array}$ & $\begin{array}{c}\text { Measurement } \\
\text { date } \\
\text { (yyyy/dd/mm) }\end{array}$ & $\begin{array}{c}\text { Ecorr } \\
(\mathrm{mV}, \mathrm{SCE})\end{array}$ & $\begin{array}{c}\text { Re+Rp } \\
1 / \mathrm{slope} \\
(\text { Ohm) }\end{array}$ & $\begin{array}{c}\text { Linear } \\
\text { regression }\end{array}$ & $\begin{array}{c}\text { Re } \\
\text { Nyquist } \\
(\text { Ohm })\end{array}$ & $\begin{array}{c}\mathrm{i}_{\text {corr }} \\
\left(\mu \mathrm{A} / \mathrm{cm}^{2}\right)\end{array}$ & Comments \\
\hline 0 & $2008 / 09$ & -410 & 7608 & 1.00 & 857 & 0.20 & - \\
3 & $2008 / 19 / 12$ & -388 & 3097 & 1.00 & 407 & 0.51 & - \\
6 & $2009 / 21 / 04$ & -373 & 4115 & 1.00 & 729 & 0.41 & - \\
9 & $2009 / 23 / 06$ & -328 & 5256 & 0,98 & 1110 & 0.33 & - \\
12 & $2009 / 23 / 09$ & -337 & 3111 & 1.00 & 1986 & 1.23 & - \\
15 & $2010 / 15 / 01$ & -408 & 2255 & 1.00 & 934 & 1.04 & - \\
18 & $2010 / 09 / 04$ & -387 & 3333 & 1.00 & 1417 & 0.72 & - \\
21 & $2010 / 11 / 06$ & -405 & 2445 & 0.99 & 1204 & 1.11 & - \\
24 & $2010 / 17 / 09$ & -435 & 2487 & 1.00 & 1479 & 1.37 & small cracks \\
27 & $2011 / 25 / 01$ & -450 & 2048 & 1.00 & 1026 & 1.35 & small cracks \\
30 & $2011 / 21 / 06$ & -368 & 3686 & 1.00 & 1774 & 0.72 & small cracks \\
33 & $2011 / 29 / 09$ & -395 & 3173 & 1.00 & 2224 & 1.45 & small cracks \\
36 & $2011 / 20 / 12$ & -456 & 1770 & 1.00 & 1166 & 2.28 & small cracks \\
39 & $2012 / 29 / 03$ & -379 & 4369 & 1.00 & 2943 & 0.97 & small cracks \\
42 & $2012 / 06 / 07$ & -299 & 4138 & 1.00 & 2796 & 1.03 & small cracks \\
45 & $2012 / 18 / 09$ & -356 & 5101 & 1.00 & 4383 & 1.92 & small cracks \\
48 & $2012 / 16 / 11$ & -370 & 3365 & 1.00 & 2540 & 1.67 & small cracks \\
51 & $2013 / 15 / 03$ & -339 & 4996 & 1.00 & 3947 & 1.32 & small cracks \\
54 & $2013 / 05 / 07$ & -280 & 7676 & 1.00 & 6984 & 1.99 & small cracks \\
57 & $2013 / 26 / 09$ & -299 & 6925 & 1.00 & 6298 & 2.20 & small cracks \\
60 & $2014 / 16 / 01$ & -319 & 5882 & 0.98 & 5168 & 1.93 & small cracks
\end{tabular}

3.1. Corrosion rates, $i_{\text {corr }}$

Corrosion rates versus the measurement termed points are presented in Figure 3 and in Figure 4 for specimens exposed to controlled environmental conditions and in Figure 5 for specimens exposed to outdoor conditions. The corrosion rate is an instantaneous value (represented by a histogram bar) which corresponds to a concrete state, an environmental condition and a measurement termed point. The first white histogram bar corresponds to the corrosion state of the prisms before being placed in the environmental conditions and therefore it cannot be compared directly with the other bars. 


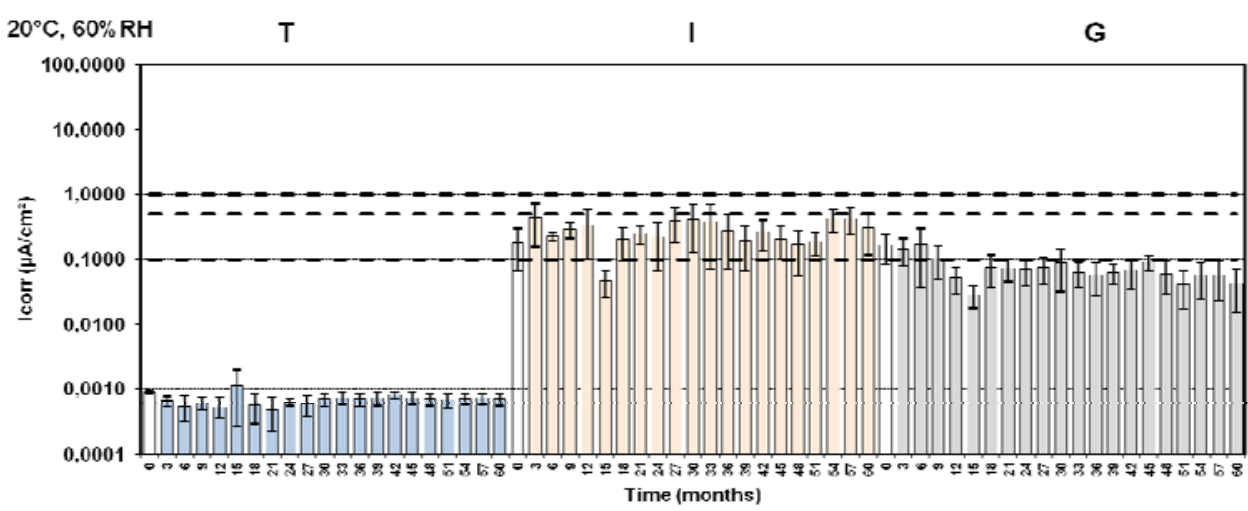

(a)

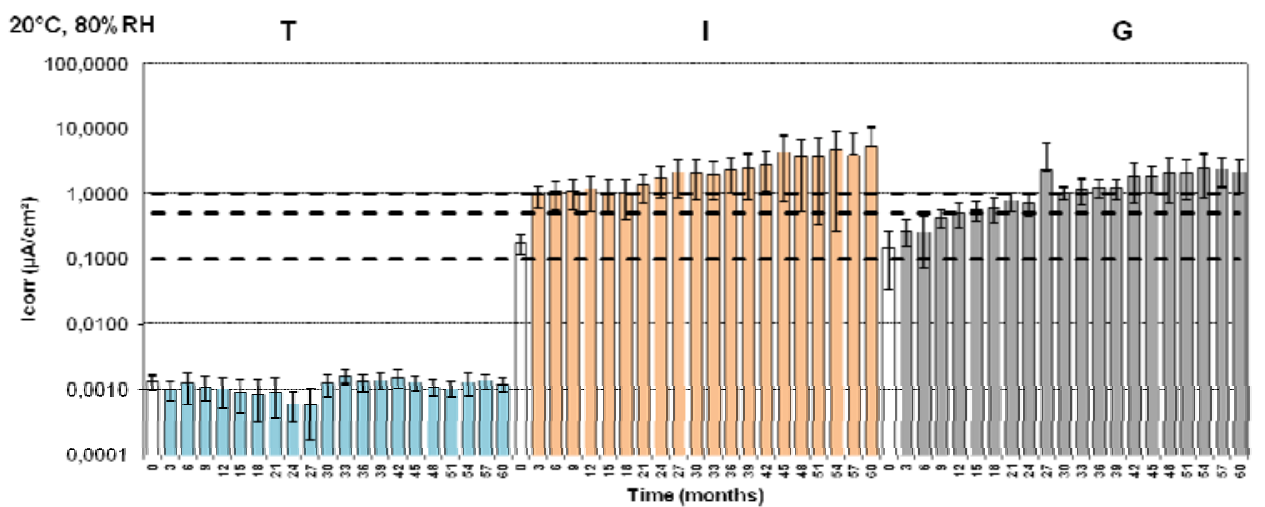

(b)

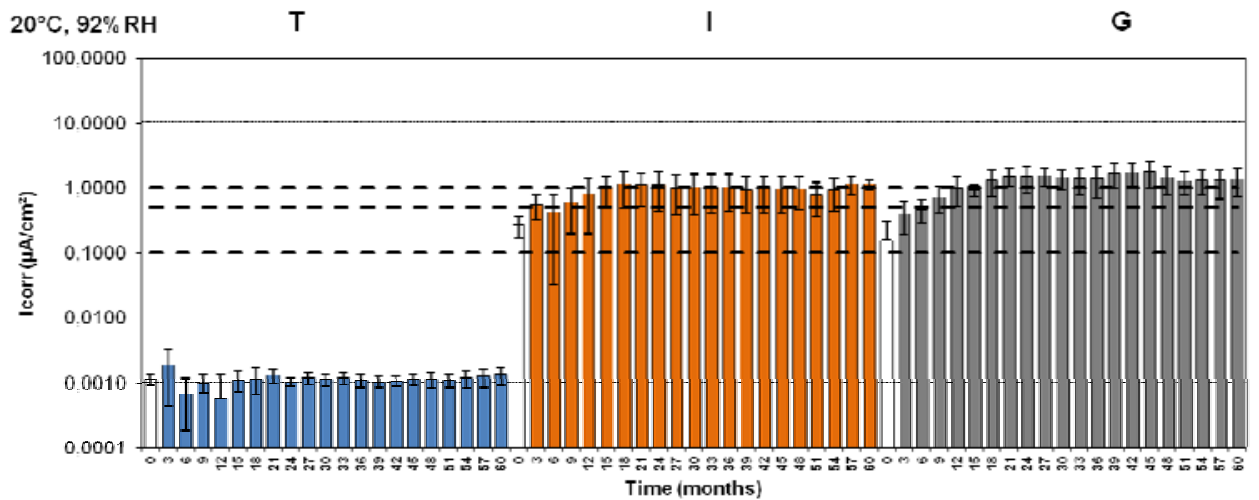

(c)

Figure 3: Corrosion rates versus measurement termed points for the reinforced concretes ( $T$, I and $G)$ exposed to controlled environmental conditions at $20^{\circ} \mathrm{C}$ and $60 \% R H(a), 80 \% R H(b)$ and $92 \% R H(c)$. The dotted lines represent the corrosion levels as indicated in [27]. 


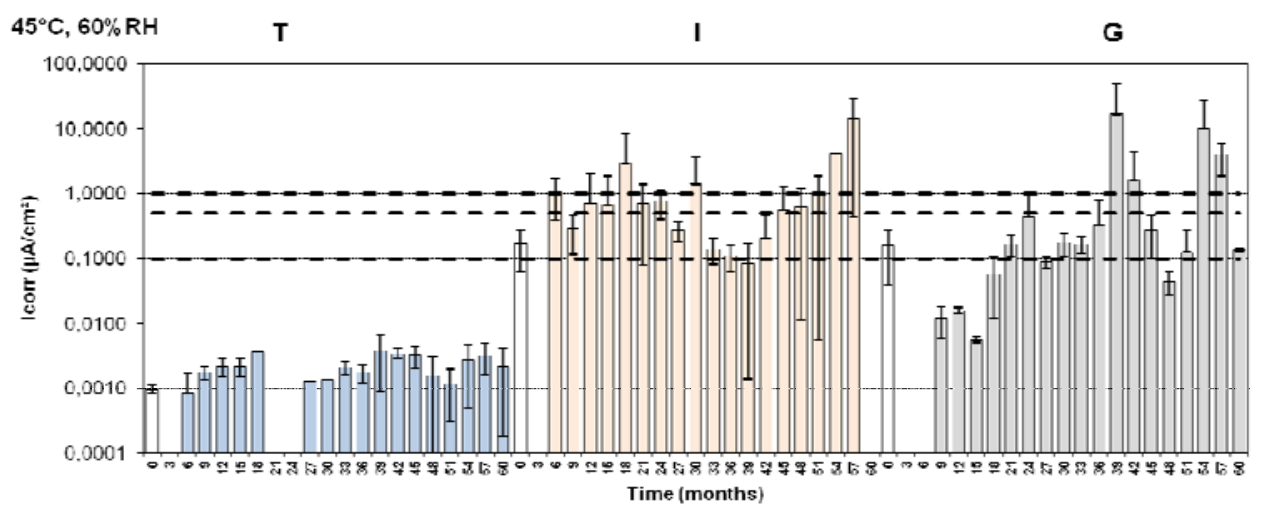

(a)

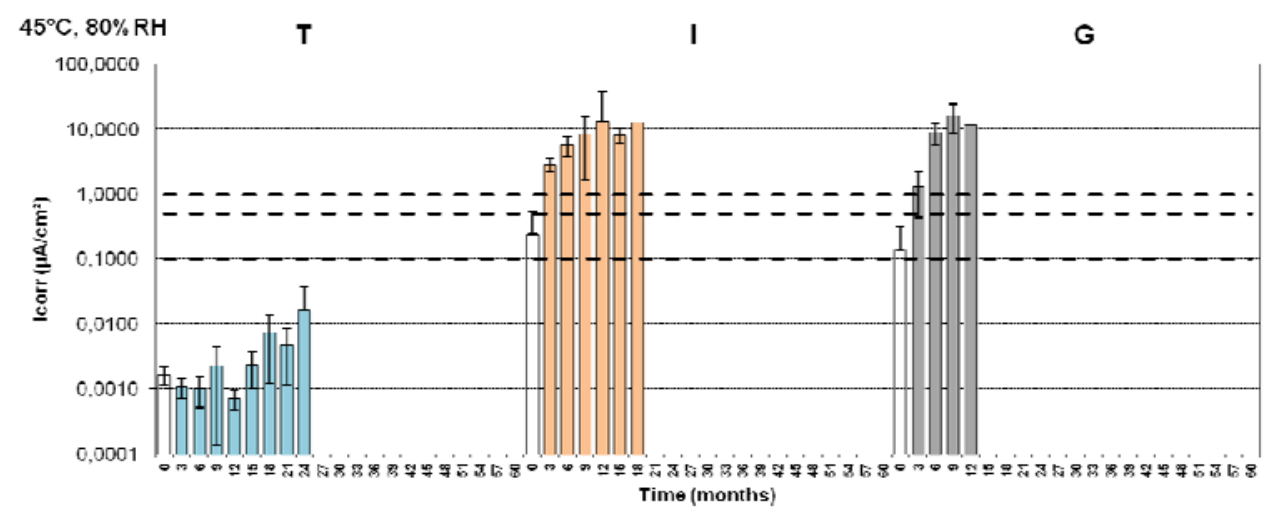

(b)

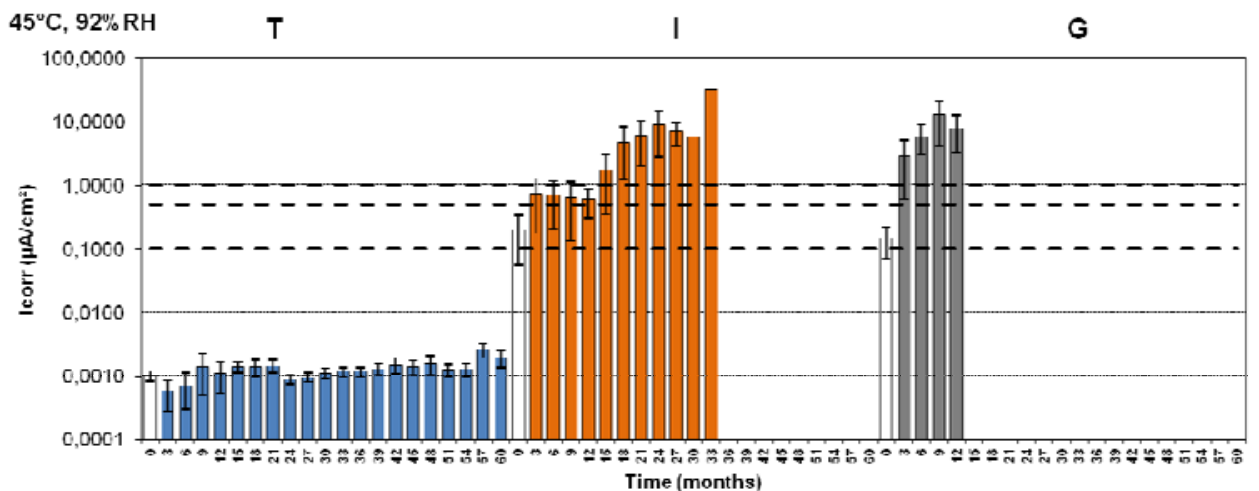

(c)

Figure 4: Corrosion rates versus measurement termed points for the reinforced concretes ( $T$, I and $G)$ exposed to controlled environmental conditions at $45^{\circ} \mathrm{C}$ and $60 \% R H(a), 80 \% R H(b)$ and $92 \% R H(c)$. The dotted lines represent the corrosion levels as indicated in [27]. 


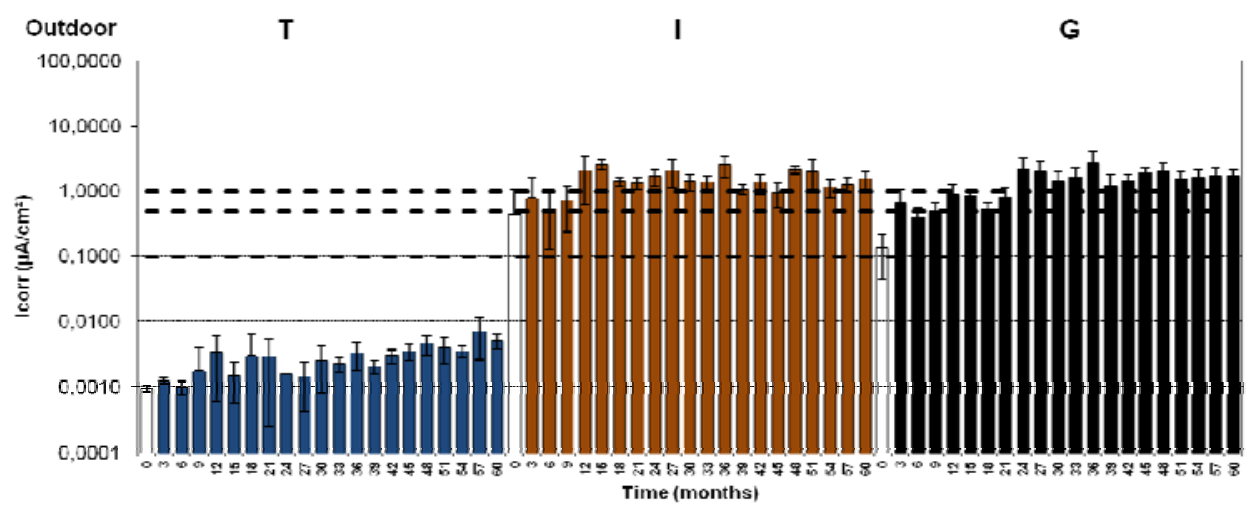

Figure 5: Corrosion rates versus measurement termed points for the reinforced concretes ( $T, I$ and $G)$ exposed to outdoor environmental conditions. The dotted lines represent the corrosion levels as indicated in [27].

In sound reinforced concrete $\mathrm{T}$, as expected, rebars remained passive (with $\mathrm{i}_{\text {corr }}$ values below $\left.0.01 \mu \mathrm{A} / \mathrm{cm}^{2}[27]\right)$ through the five year study whatever the environmental conditions were (controlled or not). At $20^{\circ} \mathrm{C}$, corrosion of chloride contaminated reinforced concretes were in the ranges negligible to moderate for a relative humidity of $60 \%$ and in the ranges moderate to high for relative humidities of 80 and $92 \% \mathrm{RH}$. These results showed that the corrosion process cannot only be attributed to a chloride content (which is quite high (§ 2.2)) but also to an environmental condition and these two parameters need to be considered together. Increases of temperature from 20 to $45^{\circ} \mathrm{C}$ lead to a more severe corrosion with higher $\mathrm{i}_{\text {corr }}$ values and the occurrence of cracks or even delamination. In outdoor environmental conditions (Figure 5), $\mathrm{i}_{\text {corr }}$ values were in the moderate to high corrosion levels. Depending on the measurement termed points, they showed small fluctuations which could be explained by the evolution of corrosion as well as by the temperature and relative humidity changes (Figure 1). Studies in outdoor conditions have demonstrated as general trends that corrosion results usually follow the day/night cycles or the year-seasonal cycles, sheltered or unsheltered conditions [16]. The influence of a rain event has also been mentioned [15].

\section{Discussion}

Prediction of the durability of a reinforced concrete over several decades of years is usually calculated considering one single $\mathrm{i}_{\text {corr }}$ value (because of the unique diagnosis) and considering that the corrosion is linear with time. The aim of this work is to propose a mathematical relation of cumulative steel 
thickness loss with time related to the propagation phase of corrosion for reinforced concrete contaminated with chlorides. This relation was expressed as the cumulative steel thickness loss because for civil engineering calculations steel thickness is more useful than corrosion rate. In this discussion section, three items are pointed out: (i) the search of a mathematical relation that best fitted the obtained experimental results in order to simulate the corrosion, (ii) the reliability of the evaluation of steel thickness loss depending on the input $\mathrm{i}_{\text {corr }}$ value and the mathematical relation assumption and (iii) the steel thickness loss that induced cover cracking.

\subsection{Mathematical relation of cumulative steel thickness loss with time}

Based on the corrosion rate values, cumulative steel thickness loss were calculated and plotted versus time. In order to fit the whole series of experimental points for the five year period, two mathematical relations were tested: a linear (graphs are not represented here) and a power (Figure 6, Figure 7 and Figure 8). Table 4 gathers the equations together with the regression coefficients. In all cases, the power relation was more satisfactory than the linear one. The obtained $\alpha$ value was higher than one and indicated that in presence of chloride ions at the rebar level, once the corrosion has begun it increases. The increase could not be directly linked to the appearance of cracks (as an example, $\mathrm{G}$ prisms exposed to $20^{\circ} \mathrm{C}$ and $60 \% \mathrm{RH}$ did not crack and still their corrosion increased). Moreover, as the prisms were not submitted to a chloride exposure the increase could not be attributed to a migration of chloride ions through the cracks. Therefore, the reaction probably became self-catalytic. Results also highlighted that when temperature increased corrosion increased and so did the a value. Focusing on the reinforced concrete prisms exposed to $45^{\circ} \mathrm{C}$ and a $60 \% \mathrm{RH}$, the experimental points rather showed two or three segments as if the corrosion process was undergoing different stages. The results reported herein suggest an acceleration of the corrosion with time for reinforcements in concretes contaminated by chloride ions. They are not in agreement with the attenuation of the corrosion (alpha value being smaller than one) found for bare steel in marine environments [45]. The discrepancy of both results can probably be explained by the availability of oxygen and moisture that are different in atmospheric conditions or in concrete containment.

Another possibility of analyzing the data would have been to consider two linear segments: in the first segment the corrosion rates would have been representative of the specimens taking some time to be conditioned in their environment and after that, the corrosion rates change would have been 
representative of the corrosion in its propagation phase. Both approaches (power relation or two linear segments) will be discussed in a future paper with the aim of predicting the durability of reinforced concrete structures and the values obtained for longer times (tests are ongoing) will be helpful to identify the most likely. Literature on long term-corrosion will also provide some clues $[10,46]$.
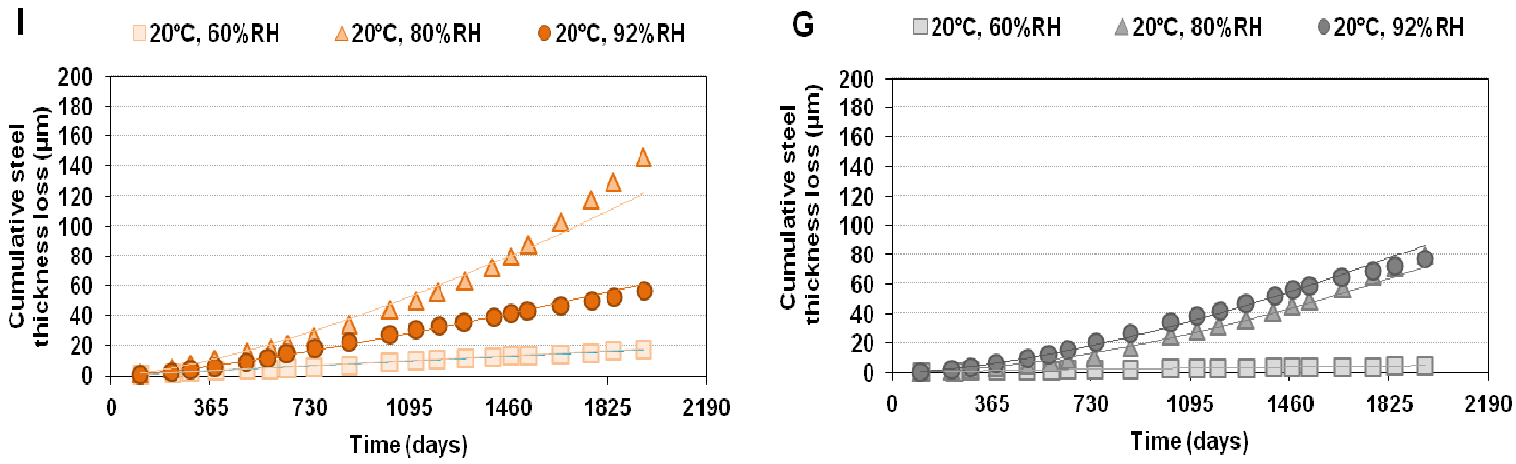

Figure 6: Experimental data points and power fitting curves of the cumulative steel thickness loss versus time for chloride contaminated reinforced concretes (I and G) exposed at $20^{\circ} \mathrm{C}$.
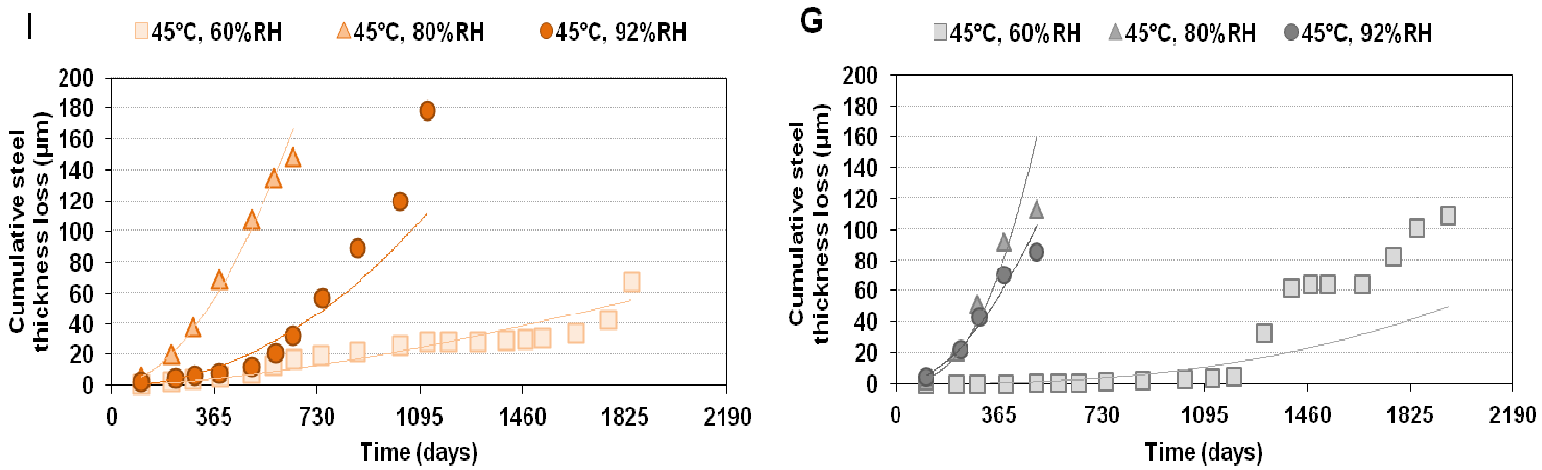

Figure 7: Experimental data points and power fitting curves of the cumulative steel thickness loss versus time for chloride contaminated reinforced concretes (I and $\mathrm{G})$ exposed at $45^{\circ} \mathrm{C}$.
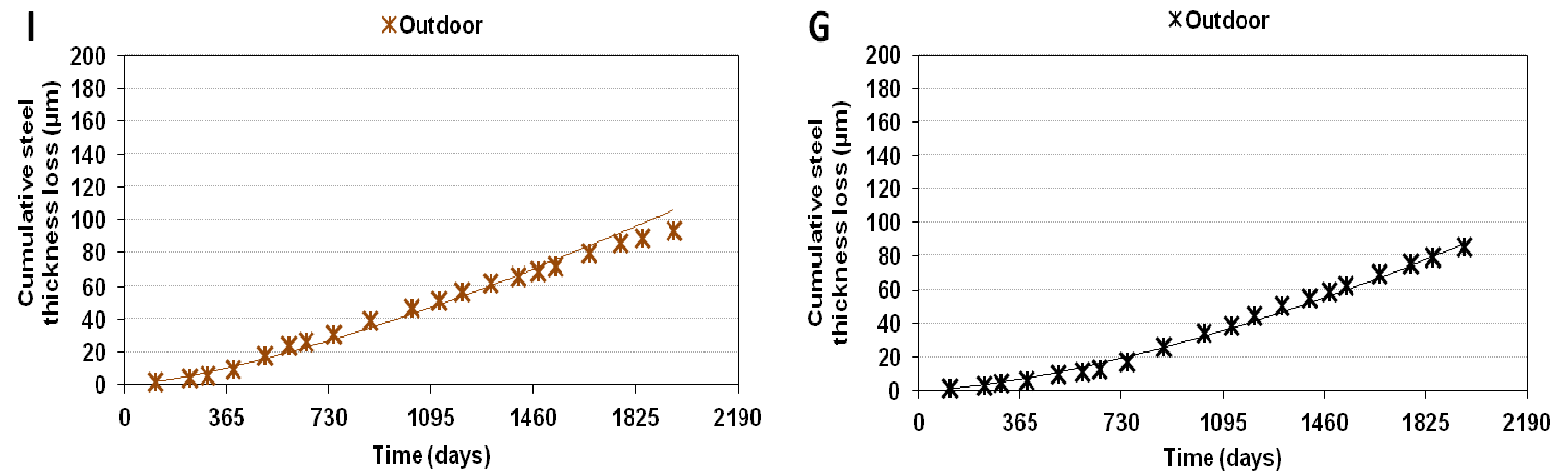

Figure 8: Experimental data points and power fitting curves of the cumulative steel thickness loss versus time for chloride contaminated reinforced concretes (I and $G$ ) exposed outdoor. 
Table 4: Mathematical relations (linear and power) of the cumulative steel thickness loss versus time for chloride contaminated reinforced concretes ( $I$ and $G$ ) depending on the environmental conditions.

\begin{tabular}{|c|c|c|c|c|c|c|c|c|}
\hline \multirow{2}{*}{$\begin{array}{c}\text { Environmental } \\
\text { conditions }\end{array}$} & \multicolumn{2}{|c|}{ I linear } & \multicolumn{2}{|c|}{ I power } & \multicolumn{2}{|c|}{ G linear } & \multicolumn{2}{|c|}{ G power } \\
\hline & $y=a t$ & $\mathrm{R}^{2}$ & $y=a t^{a^{a}}$ & $\mathrm{R}^{2}$ & $y=a t$ & $\mathrm{R}^{2}$ & $y=a t^{\alpha}$ & $\mathrm{R}^{2}$ \\
\hline $20^{\circ} \mathrm{C}, 60 \% \mathrm{RH}$ & $0.009 t$ & 0.96 & $0.0121 \mathrm{t}^{0.96}$ & 0.99 & $0.0027 t$ & 0.95 & $0.0207 t^{0.72}$ & 0.99 \\
\hline $20^{\circ} \mathrm{C}, 80 \% \mathrm{RH}$ & $0.0579 t$ & 0.89 & $0.0020 t^{1.4 t}$ & 0.99 & $0.0319 t$ & 0.88 & $0.0002 t^{1.72}$ & 0.99 \\
\hline $20^{\circ} \mathrm{C}, 92 \% \mathrm{RH}$ & $0.0278 \mathrm{t}$ & 0.99 & $0.0026 \mathrm{t}^{1.33}$ & 0.99 & $0.0368 \mathrm{t}$ & 0.96 & $0.0006 t^{1.6}$ & 0.99 \\
\hline $45^{\circ} \mathrm{C}, 60 \% \mathrm{RH}$ & $0.0238 t$ & 0.86 & $0.0004 t^{1.5 \varepsilon}$ & 0.95 & $0.036 \mathrm{t}$ & 0.64 & $1 \mathrm{E}-7 \mathrm{t}^{2.64}$ & 0.78 \\
\hline $45^{\circ} \mathrm{C}, 80 \% \mathrm{RH}$ & $0.2089 t$ & 0.92 & $0.0007 \mathrm{t}^{1.9}$ & 0.99 & $0.2079 t$ & 0.88 & $2 E-05 t^{2.59}$ & 0.97 \\
\hline $45^{\circ} \mathrm{C}, 92 \% \mathrm{RH}$ & $0.1353 t$ & 0.81 & $3 \mathrm{E}-5 \mathrm{t}^{2.16}$ & 0.96 & $0.1613 t$ & 0.92 & $0.0007 t^{1.92}$ & 0.99 \\
\hline Outdoor & $0.0467 \mathrm{t}$ & 0.99 & $0.003 t^{1.38}$ & 0.99 & $0.0392 \mathrm{t}$ & 0.94 & $0.0008 \mathrm{t}^{1.53}$ & 0.99 \\
\hline
\end{tabular}

4.2. Reliability of the evaluation of steel thickness loss depending on input $\mathrm{i}_{\text {corr }}$ value and mathematical relation assumption

For $\mathrm{G}$ prisms exposed to outdoor environmental conditions, Figure 9 illustrates the cumulative steel thickness loss versus time considering three scenarios (i) the minimum value of $i_{\text {corr }}\left(0.4 \mu \mathrm{A} / \mathrm{cm}^{2}\right.$ at 6 months, Figure 5) and a linear relation, (ii) the maximum value of $\mathrm{i}_{\text {corr }}\left(2.7 \mu \mathrm{A} / \mathrm{cm}^{2}\right.$ at 36 months, Figure 5) and a linear relation and (iii) the whole set of $i_{\text {corr }}$ values and a power relation. After five years, based on the third scenario, the steel thickness loss was equal to $80 \mu \mathrm{m}$. This value is to be compared to the one obtained considering a single $\mathrm{i}_{\text {corr }}$ value and a linear relationship for five years (as done in practice) which corresponded to $20 \mu \mathrm{m}$ for the minimum value of $i_{\text {corr }}$ and to $160 \mu \mathrm{m}$ for the maximum value of $\mathrm{i}_{\text {corr }}$ (an eightfold increase !). For I prisms contaminated by chlorides that penetrated through wetting/drying cycles and which were therefore more similar to what happens on-site, the steel thickness losses were $97 \mu \mathrm{m}$ (whole set of $\mathrm{i}_{\text {corr }}$ values), $31 \mu \mathrm{m}$ ( $\mathrm{i}_{\text {corr }} \min =0.53 \mu \mathrm{A} / \mathrm{cm}^{2}$ at 6 months) and $150 \mu \mathrm{m}\left(\mathrm{i}_{\mathrm{corr}} \max =2,56 \mu \mathrm{A} / \mathrm{cm}^{2}\right.$ at 36 months) (graph not shown).

These results demonstrate that considering only one $\mathrm{i}_{\text {corr }}$ value can result in an under-estimation or an over-estimation of the corrosion process as mentioned in [47]. A frequent measurement or even a monitoring of the corrosion rate is necessary for providing reliable data that will undoubtedly be very useful for prediction issues. 


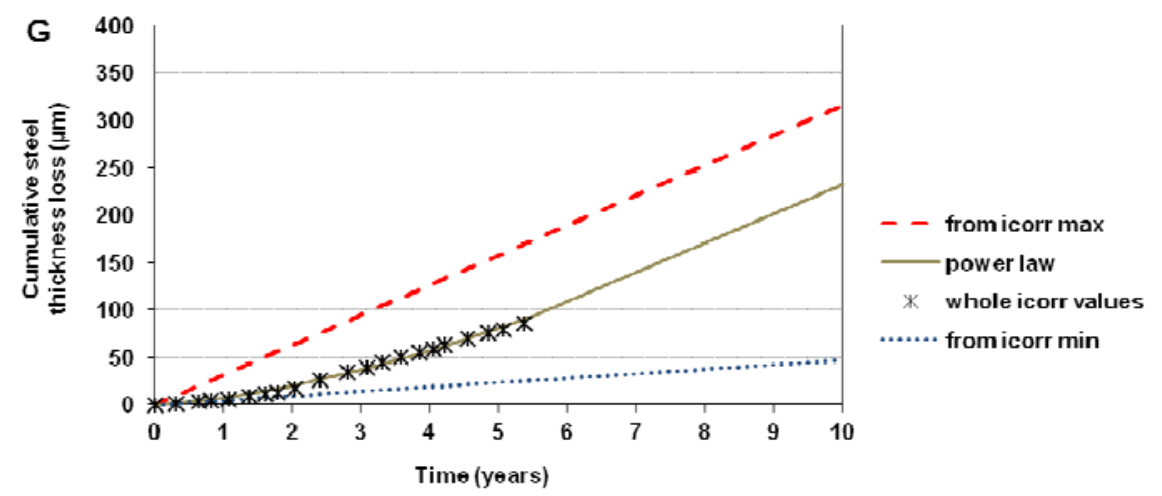

Figure 9: Cumulative steel thickness loss versus time for $G$ prisms exposed to outdoor environmental conditions for prediction purpose (considering the maximum or the minimum $i_{\text {corr }}$ value and a linear relation or considering the whole set of $i_{\text {corr }}$ values and the power relation).

\subsection{Steel thickness loss that induced concrete cover cracking}

For bridge owners, concrete cover cracking is an indicator of corrosion.

Table 5 presents the steel thickness loss that induced the concrete cover cracking. It was determined using the first crack appearance time from the visual inspections and the mathematical power relations. From these figures a steel thickness loss value close to $20 \mu \mathrm{m}$ could be proposed. However the volume increase of the corrosion products also participates to the concrete expansion and ultimately the cover cracking [48].

Table 5: Steel thickness loss that induced concrete cover cracking (determined from first crack appearance time and the mathematical power relation).

\begin{tabular}{ccccc}
\hline $\begin{array}{c}\text { Environmental } \\
\text { condition }\end{array}$ & $\begin{array}{c}\mathrm{t}_{\text {crack }} \text { from visual } \\
\text { inspection } \\
\text { (months) }\end{array}$ & $\begin{array}{c}\text { Steel thickness } \\
\text { loss } \\
(\mu \mathrm{m})\end{array}$ & $\begin{array}{c}\mathrm{t}_{\text {crack }} \text { from visual } \\
\text { inspection } \\
\text { (months })\end{array}$ & $\begin{array}{c}\text { Steel thickness } \\
\text { loss } \\
(\mu \mathrm{m})\end{array}$ \\
\hline $20^{\circ} \mathrm{C}, 60 \% \mathrm{RH}$ & 45 & 16 & - & \\
$20^{\circ} \mathrm{C}, 80 \% \mathrm{RH}$ & 15 & 14 & 45 & 50 \\
$20^{\circ} \mathrm{C}, 92 \% \mathrm{RH}$ & - & - & 57 & 79 \\
\hline $45^{\circ} \mathrm{C}, 60 \% \mathrm{RH}$ & 15 & 6 & 45 & 19 \\
$45^{\circ} \mathrm{C}, 80 \% \mathrm{RH}$ & 15 & 84 & 6 & 14 \\
$45^{\circ} \mathrm{C}, 92 \% \mathrm{RH}$ & 18 & 25 & 6 & 15 \\
\hline Outdoor & 18 & 18 & 24 & 22 \\
\hline
\end{tabular}

\section{Conclusions}

Results obtained through this intensive and quite long-term experimental program (105 reinforced concrete prisms, 3 concrete states, 7 environmental conditions, 4 times per year measurements, more 
than 5 year study) were gathered in a database consisting on non-destructive electrochemical measurements, calculations of corrosion rates and visual observations. Based on the corrosion rate values, it was found that a mathematical power relation of cumulative steel thickness loss with time, for each concrete state and for each environmental condition, fitted the experimental values better than a linear relation. The alpha power value was larger than one, indicating that once the corrosion begins, the reaction becomes self-catalytic. It was demonstrated that frequent measurements or even monitoring should be used in order to increase the reliability of the simulation and/or the prediction of the durability of reinforced concrete. After a five year study, figures of steel thickness loss for reinforced concrete contaminated with chloride in the mix exposed to outdoor conditions were $80 \mu \mathrm{m}$ based on 20 measurements compared to $20 \mu \mathrm{m}$ or $160 \mu \mathrm{m}$ based on a single measurement (min $\mathrm{i}_{\text {corr }}$ or max $i_{\text {corr }}$ respectively). Finally, based on the visual observations and the power relations, it was possible to calculate the steel thickness loss responsible for the concrete cover cracking. This information would be useful for numerical studies for example.

The mathematical relations reported in this paper belong to a particular experimental program and should be validated on other cases and on real structures. This study is still ongoing and future results will be analysed to confirm that the power relation (or the two linear segments) can correctly describe the long-term corrosion of chloride contaminated reinforced concretes.

\section{Acknowledgements}

The authors would like to thank G. Biadala (from LR Lille), F. Boinski and J. Schneider (from LREP Melun) for the fabrication and the ageing of the reinforced concrete slabs. They also thank $\mathrm{J}$. Dauthuille, A. Deman, J-F. Cherrier, U. Iftikhar and N. Coulaty (from Ifsttar) for the electrochemical measurements and B. Koubi (from Ifsttar) for the macro development.

Finally, V. L'Hostis from CEA Saclay and C. Andrade from IETcc in Spain are particularly acknowledged for helpful scientific discussions as partners of this national project.

Investigations and results reported herein were supported from 2007 to 2010 by the National Research Agency (France) within the APPLET research program (grant ANR-06-RGCU-001-01) and from 2010 to 2014 by Ifsttar and LRMH. 


\section{References}

[1] Tilly GP, Jacobs J. CONREPNET - Concrete repairs - Performance in service and current practice. United Kingdom: IHS BRE Press; 2007.

[2] Bentur A, Diamond S, Berke NS. Steel corrosion in concrete - Fundamentals and civil engineering practice. London, United Kingdom: E\&FN SPON; 1997.

[3] Broomfield JP. Corrosion of steel in concrete - Understanding, investigation and repair. London: E\&FN SPN; 1997.

[4] Bertolini L, Elsener B, Pedeferri P, Polder R. Corrosion of steel in concrete: prevention, diagnosis, repair. Weinheim: Wiley Vch Verlagsgesellschaft Mbh; 2004.

[5] Audisio S, Béranger G, Bouteiller V. Anticorrosion et durabilité dans le bâtiment, le génie civil et les ouvrages industriels ; Chapitre 18 Les traitements électrochimiques pour la réhabilitation du béton armé dégradé. . Presses Polytechniques et Universitaires Romandes ed2010.

[6] Raharinaivo A, Arliguie G, Chaussadent T, Grimaldi G, Pollet V, Tache G. La corrosion et la protection des aciers dans le béton. Paris: Presses de l'école nationale des Ponts et Chaussées; 1998.

[7] Ahmad S. Reinforcement corrosion in concrete structures, its monitoring and service life prediction—a review. Cement and Concrete Composites. 2003;25(4-5):459-71.

[8] Alonso C, Andrade C, Castellote M, Castro P. Chloride threshold values to depassivate reinforcing bars embedded in a standardized OPC mortar. Cement and Concrete Research. 2000;30(7):1047-55.

[9] Angst U, Elsener B, Larsen CK, Vennesland Ø. Critical chloride content in reinforced concrete - A review. Cement and Concrete Research. 2009;39(12):1122-38.

[10] Melchers RE, Li CQ. Reinforcement corrosion initiation and activation times in concrete structures exposed to severe marine environments. Cement and Concrete Research. 2009;39(11):1068-76.

[11] Bouteiller V, Cremona C, Baroghel-Bouny V, Maloula A. Corrosion initiation of reinforced concretes based on Portland or GGBS cements: Chloride contents and electrochemical characterizations versus time. Cement and Concrete Research. 2012;42(11):1456-67.

[12] Angst U, Rønnquist A, Elsener B, Larsen CK, Vennesland Ø. Probabilistic considerations on the effect of specimen size on the critical chloride content in reinforced concrete. Corrosion Science. 2011;53(1):177-87.

[13] Millard SG, Law D, Bungey JH, Cairns J. Environmental influences on linear polarisation corrosion rate measurement in reinforced concrete. NDT \& E International. 2001;34(6):409-17.

[14] Pech-Canul MA, Castro P. Corrosion measurements of steel reinforcement in concrete exposed to a tropical marine atmosphere. Cement and Concrete Research. 2002;32(3):491-8.

[15] Andrade C, Alonso C, Sarria J. Corrosion rate evolution in concrete structures exposed to the atmosphere. Cement and Concrete Composites. 2002;24(1):55-64.

[16] Andrade C, Castillo A. Evolution of reinforcement corrosion due to climatic variations. Materials and Corrosion. 2003;54:379-86.

[17] Bouteiller V, Cherrier J-F, L'Hostis V, Rebolledo N, Andrade C, Marie-Victoire E. Influence of humidity and temperature on the corrosion of reinforced concrete prisms. European Journal of Environmental and Civil Engineering. 2012;16(3-4):471-80.

[18] So HS, Millard SG. On-site measurements on corrosion rate of steel in reinforced concrete. ACI Materials Journal. 2007;104:638-42. 
[19] Trocónis de Rincón O, Sánchez M, Millano V, Fernández R, de Partidas EA, Andrade C, et al. Effect of the marine environment on reinforced concrete durability in Iberoamerican countries: DURACON project/CYTED. Corrosion Science. 2007;49(7):2832-43.

[20] Hussain RR. Effect of moisture variation on oxygen consumption rate of corroding steel in chloride contaminated concrete. Cement and Concrete Composites. 2011;33(1):154-61.

[21] Andrade C, Alonso C, Garcia AM. Oxygen availability in the corrosion of reinforcements. Advances in Cement Research. 1990;3(11):1276132.

[22] Toro L, Andrade C, Fullea J, Martínez I, Rebolledo N. Steel corrosion in a chloride contaminated concrete pore solution with low oxygen availability. 4th International RILEM $\mathrm{PhD}$ workshop. Madrid, Spain2010.

[23] Andrade C, Alonso C. Corrosion rate monitoring in the laboratory and on-site. Construction and Building Materials. 1996;10(5):315-28.

[24] Andrade C, Martinez I. Calibration by gravimetric losses of electrochemical corrosion rate measurement using modulated confinement of the current. Materials and Structures. 2005;38:833-41.

[25] Scully JR. Polarization resistance method for determination of instantaneous corrosion rates. Corrosion. 2000;56(2):199-217.

[26] Grantham MG, Herts B, Broomfield J. The use of linear polarisation corrosion rate measurements in aiding rehabilitation options for the deck slabs of a reinforced concrete underground car park. Construction and Building Materials. 1997;11(4):215-24.

[27] Andrade C, Alonso C. RILEM TC 154-EMC:Electrochemical Techniques for Measuring Metallic Corrosion - Recommendations - Test methods for on-site corrosion rate measurement of steel reinforcement in concrete by means of the polarization resistance method. Materials and Structures. 2004;37:623-43.

[28] Law DW, Cairns J, Millard SG, Bungey JH. Measurement of loss of steel from reinforcing bars in concrete using linear polarisation resistance measurements. NDT \& E International. 2004;37(5):381-8.

[29] Marie-Victoire E, Bouteiller V, Garciaz JL, Cherrier JF, Dauthuille J, Marzin F, et al. On-site instantaneous corrosion rate measurements on a historical building. European Journal of Environmental and Civil Engineering. 2012;16(3-4):505-23.

[30] Elsener B. RILEM TC 154-EMC:Electrochemical Techniques for Measuring Metallic Corrosion - Recommendations - Half-cell potential measurements - Potential mapping on reinforced concrete structures. Materials and Structures. 2003;36:461-71.

[31] Polder R. RILEM TC 154-EMC:Electrochemical Techniques for Measuring Metallic Corrosion - Recommendations - Test methods for on-site measurements of resistivity of concrete. Materials and Structures. 2000;33:603-11.

[32] Andrade C, González JA. Quantitative measurements of corrosion rate of reinforcing steels embedded in concrete using polarization resistance measurements. Werkstoffe und Korrosion. 1978;29:515-9.

[33] Wenger F. Etude de la corrosion de l'acier doux dans le béton par des méthodes électrochimiques. Orsay, France: Doctorial Thesis, Université Paris Sud; 1986.

[34] Feliu S, González JA, Andrade MC, Feliu V. Determining polarization resistance in reinforced concrete slabs. Corrosion Science. 1989;29(1):105-13.

[35] Keddam M. Principes et applications des techniques électrochimiques en corrosion. Matériaux et Techniques. 1994(1-2):39-45.

[36] Law DW, Millard SG, Bungey JH. Linear polarisation resistance measurements using a potentiostatically controlled guard ring. NDT \& E International. 2000;33(1):15-21.

[37] Andrade C, Alonso C. On-site measurements of corrosion rate of reinforcements. Construction and Building Materials. 2001;15(2-3):141-5. 
[38] Martinez I, Andrade C, Rebolledo N, Bouteiller V, Marie-Victoire E, Olivier G. Corrosion characterization of reinforced concrete slabs with different devices. Corrosion. 2008;64(2):107-23.

[39] Otieno MB, Beushausen HD, Alexander MG. Modelling corrosion propagation in reinforced concrete structures - A critical review. Cement and Concrete Composites. 2011;33(2):240-5.

[40] Otieno M, Beushausen $\mathrm{H}$, Alexander M. Prediction of corrosion rate in reinforced concrete structures - a critical review and preliminary results. Materials and Corrosion. 2012;63(9):777-90.

[41] Castellote M, Andrade C. RILEM TC 178-TMC : Testing and modelling chloride penetration in concrete - Round robin test on chloride analysis in concrete Part 1 : Analysis of total chloride content. Materials and Structures. 2001;34:532 (Procedure A3-C4*).

[42] Castellote M, Andrade C. RILEM TC 178-TMC : Testing and modelling chloride penetration in concrete - Round robin test on chloride analysis in concrete Part 2 : Analysis water soluble chloride content. Materials and Structures. 2001;34:589 (Procedure B1).

[43] AFNOR. NF EN 206-1 / P18-325-1. Béton : spécification, performances, production et conformités. 2004.

[44] Stern M, Geary AL. Electrochemical polarization. I - A theoretical analysis of the shape of polarization curves. Journal of Electrochemical Society. 1957;104:56-65.

[45] Melchers RE. Long-term corrosion of steels exposed to marine environments. European Journal of Environmental and Civil Engineering. 2009;13:527-46.

[46] Melchers RE. Long-term corrosion of cast irons and steel in marine and atmospheric environments. Corrosion Science. 2013;68:186-94.

[47] Cremona C, Rougeaud P, Torrenti JM, Poyet S, Adelaide L, Berthaud Y, et al. Durée de vie des ouvrages en béton armé - Approche prédictive, performantielle et probabiliste Recommandations du projet ANR-APPLET: IFSTTAR - CERIB; 2012.

[48] Bhargava K, Ghosh AK, Mori Y, Ramanujam S. Modeling of time to corrosion-induced cover cracking in reinforced concrete structures. Cement and Concrete Research. 2005;35(11):2203-18. 
Nom du document : $\quad$ Revision-manuscript-20160708-VR.docx

Répertoire : I:IBouteillerlsynchrolDonnees proIPUBLISI2015-Construction-and-

Building-Materials-Loi-de-corrosionIReviewingIVR-20160708

Modèle :

C:IUsers|bouteillAppDatalRoaming|Microsoft|Templates|Normal.dotm

Titre :

Sujet :

Auteur:

Mots clés :

MLV_Formation06

Commentaires :

Date de création : $\quad$ 08/07/2016 15:46:00

$\mathrm{N}^{\circ}$ de révision:

5

Dernier enregistr. le : 08/07/2016 16:41:00

Dernier enregistrement par : bouteiller

Temps total d'édition : 214 Minutes

Dernière impression sur : $\quad$ 02/09/2016 18:00:00

Tel qu'à la dernière impression

Nombre de pages : 21

Nombre de mots : 10007 (approx.)

Nombre de caractères : 55039 (approx.) 